\title{
The so-called mythical islands of the Atlantic in Mediæval maps
}

\section{William H. Babcock}

To cite this article: William H. Babcock (1915) The so\#called mythical islands of the Atlantic in Mediæval maps, Scottish Geographical Magazine, 31:10, 531-541, DOI: 10.1080/00369221508734208

To link to this article: http://dx.doi.org/10.1080/00369221508734208

Published online: 27 Feb 2008.

Submit your article to this journal

山ll Article views: 5 
whole land, scattered widely over the upland volcanic regions: and there is little prospect of an increase in their number at present. This is a serious economic disadvantage, for in 1912 the wool imported was valued at over 16 million yen-about $£ 1,700,000$. Of this enormous quantity, half came from Australia, and a little less than half from the United Kingdom, while small amounts were brought from China and Germany.

Goats are fairly numerous, especially in Taiwan, where, in 1911, they numbered about 130,000, out of a total of under 230,000 for the whole of the Japanese islands.

\section{THE SO-CALLED MYTHICAL ISLANDS OF THE ATLANTIC IN MEDIEVAL MAPS. ${ }^{1}$}

By Williaj H. Babcock.

The Crescent Isiand of Man.

Trus island (otherwise Brazir, Mam, Mayda, Asmayda, Bentusle, Bolunda, and Vlaanderen) does not appear in the maps of Dalorte, Dulcert, or Gaddiano (the Atlante Mlediceo). Its entrance on the scene, as the records stand, is more than forty years later than that of Brazil: thereafter it becomes an almost inseparable consort of the latter for several centuries. When either is absent, both are absent; and when both are present, this Man, by whatever name, usually lies south-west or west of south of Brazil, the distance being variable in some instances, but fairly constant as a rule. It sometimes approaches a halfmoon in contour, is sometimes a mere shred or paring of a crescent, but more often has an intermediate form, being nearly always rounded smoothly on one side, and concave or nearly straight on the other, which is more or less indented as if by bays, and in a majority of cases turned to the north-west. Its names are numerous, but at first Man predominates, and in later centuries Mayda, with slight variations in each case. Neither of these names, however, was the earliest which it bore, so far as we know.

Step by step the delineation of the eastern Atlantic island-clusters and island-series had proceeded, until the Atlante Medice, 1351, showed in full the Canaries, the Madeiras, and the Azores, in the majority of instances with their present names, and marshalled correctly the subgroups of the latter archipelago, two islands in the lowest group, five in the middle, two more in the outermost. It erred only in relative direction, distance from Europe, and some details of size and form.

Then there was a curious interruption of the chain of development. The map of the Pizigani brothers appeared in 1367, and was conspicuous at once for its apparent ignorance of what others had thus learned in 
regular gradation, and for strange new flashes of original light on geography, obviously from quite novel sources. Perhaps its most notable addition was the island Brazir, imperfectly crescentic in form, far south-west of the circular Irish Brazil (here Brazir also), which from the first had held its place south of west of Limerick and off the Blaskets, and also very far west of Brittany, being almost exactly on the parallel of Quimper and the Point du Raz, here named Cabo de Fontano. The Isle de Sein, just above this headland, still bears that name. In other words, the latitude is about the forty-eighth degree, which Prunes in 1553 gives for this island on his graduated and numbored map. This agrees protty closely with a considerable number of others earlier and later, though the island was occasionally shifted as far south as the mouth of the Loire, and more rarely as far northward as the upper Breton coast, or perhaps a little farther, such variations rarely exceeding a degree or two. This certainly leaves the impression of a very old, strong, and clear tradition connecting this island with Brittany; also with Ireland by way of Brazil, as though discoverers were helieved to have reached it from these countries.

On the American side the parallel $48^{\circ}$ traverses the Avalon peninsula of Newfoundland a little above Cape Race (once Capo de Raz) and Cape Breton, two of our earliest coast-names and main geographic pivots, obviously brought from the European Breton shore. There is no land whatever at any point between the two capes sometimes called Raz. The Atlantic Ocean is there, but at one of its narrower parts.

However, we should look lower for the region intended, since other western map-forms often appear too high in latitude, perhaps because the southward dip of the isothermal lines on that side of the sea was not well understood. Edrisi and his predecessors had divided the oblong known world into equal belts running east and west under the name of "climates," duly numbered for individual distinction, and it was easy for the idea to spread that such a belt had generally the same conditions of temperature from end to end. Minor distinctions might be made, but even yet, and in well-informed minds, the recognition of decided differences of heat and cold on the same degree of latitude usually gives rise to some surprise. Reports by mariners of the fifteenth century, of a western land with the climate of Brittany or that of Portugal, would ordinarily lead to its appearance on the map opposite the country named. Allowing for this, any real land which suggested the Crescent Island might be in southern New England or below. Comparison with the site of the Antillia inscription and statue-picture of the Pizigani map would not make this Brazir farther west than the Sargasso Sea. But perhaps the map-makers, being on quite unfamiliar ground, merely meant to mark what they considered the farthest point that had been reached by sailing - as indeed their inscriptions say-and cared little whether the distance corresponded or differed on the two parallels. We have seen reason to conjecture that the region about the St. Lawrence Gulf was tho original of the medieval island of Brazil, and as the Crescent Island is almost always shown more westward and more southward than Brazil, the logic of geography points to some nearly insular part of 
the mainland coast, like Cape Cod, or some island or islands in American waters, like the Bermudas.

Notwithstanding its unique features, indicating special sources of information, this Pizigani map displays a curious poverty in data already widely known. Of the nine Azores, beside minor islets, only Terceira appears, and it shares the name Brazir with the Crescent Island and the circular or full moon island, the first and legitimate Brazil. Both by faults and merits, this map makes a gap of sheer originality in the orderly course of cartography, which confounds all attempts to work out in that way the time of discovery or subsequent visits which it means to indicate. They may have been understood as happening in almost any previous year. The island outline, it is true, has not yet taken the perfectly conventionalised form which it most often displayed afterward, and seems more like a real island; and this may indicate recentness; but that is hardly true of the inscriptions and monsterfigures, and the roughness of the island may simply reflect the draftsman's preference or clumsiness. In mass it is much less than Brazil, as was usually the case afterward. The name Brazir is probably Celtic, as already explained, being simply a further modification of Breasail. But this is not all. Happily these early map-makers were picturesquely minded. Where we moderns give lines and names they added illustrative figures of kings and saints, mariners and savages, tents in desert places, ships and churches and sea-monsters, also symbols of divers kinds, and romantically credulous inscriptions relating to the surprising attributes of remote regions or what venturesome explorers had encountered among the perils of the deep. The Pizigani map is a remarkable example of this. In particular it uses, more fully than had been done before, the vessels of the different exploring countries, marked by their respective flags, to apportion the credit of discovery. It is not very difficult to identify them, because a practice had grown up of planting the standards at the proper strongholds on the maps.

Thus we recognise on the labouring galley near "Lancerote" (also cross-marked) the cross of Genoa, which had been borne there nearly a century before by the Genoese navigator and coloniser Maloessel, whose first name, Lancelot, still clings to it, a little modified. Also (less certainly indicative) we find a vessel with a Portuguese flag nearing home almost immediately opposite the inscription concerning the shores of Atillie (Antillia).

Yet again, we find on this map three ships, carrying Breton flags, in trouble near Brazir, opposite Brittany. The ensign may seem strange, but the incorporation of Brittany with France was yet incomplete; it enjoyed indeed an intermittent and precarious independence, and was rarely reduced to surrendering this for long. Thus it comes about that on the Dulcert map of 1339 the staff of the French banner is planted at the city of Paris, but the barred standard of Brittany at the Breton name of Nantes on the Loire, its fabric overspreading most of that peninsular province. The design is made up of horizontal bars and vertical bars. The small pennants on the pictured ships do not afford room for all; but the horizontal bars are displayed by the two ships near 
the Crescent Island, and the vertical bars by the returning one which approaches the Breton coast. There could not well be a more explicit symbolic record of a Breton voyage across sea and back, with some appalling adventures.

For all did not return. A second ship has passed the island homeward with sails spread, making good its escape. But the other, though heading the same way, is reduced to bare masts and cordage, and is sinking by the stern, where a huge decapod pulls it down, as one of his tentacles is dragging a seaman overboard. Overhead a dragon flies past, with another kidnapped sailor in his jaws.

The picture parable of warning seems to need no comment, but the map-maker has not spared this. Three neighbouring inscriptions in blurred and corrupt Latin tell us that beyond this point (Brazir) there is no navigation, because the ships are perforated; also dragons come flying suddenly to carry men away, and tawny monsters of the Arabs, ominous to ships, arise from the depths. Both "Arabe" and "Arabour" unmistakably occur; "dragones" is repeated also; the word which I have translated "tawny monsters" is apparently "fulvos," though not perfectly plain. In spite of obscurities the general drift of the message is not to be mistaken.

Thus the Pizigani believed that a small Breton fleet had visited a remote and very dangerous region of the west, incurring dire troubles and loss, and bringing home very monstrous stories of their experiences. One may conjecture that its terrors were borrowed in some measure from the Arabs, repeatedly cited as above, who are known to have been very active in this part of the sea after their conquest of the Iberian peninsula, and who at some undefined date, considerably before 1154 , had sent forth at least one expedition sworn to cross the Atlantic. Edrisi's account of their voyage relates their unsuccessful attempt to penetrate the Sargasso Sea, plainly indicated by Pizigani. Moreover, the man-stealing dragon is a cogent reminder of Sinbad's man-conveying roc. It accords with other evidence of interblending of Arab Irish legend that this island should have an Irish Gaelic name, though associated in words of explanatory inscription with the sea-Arabs and their adventures. The Bretons may have derived hints from both.

$Y$ is strange, no doubt, to find a single name shared by two islands of diametrically opposite repute : for there seems often some association of evil and danger with the Crescent Island, whatever its name on a particular map may be ; whereas the ideal of Brazil was always gracious, no less than grand, it being still, in the minds of the Irish peasantry, more or less touched with lingering memories of the blessed islands of their old mythology. The map of Fra Mauro, 1459, counted especially wise and authoritative, names it Berzil, and identifies it with the Fortunate Islands. The suggestion of the maps appears to be that Irish mariners, probably from Limerick or near it, had found a land which pleased them by sailing south or west; and again, on this or some later occasion, had found a second region more remote in the same general direction, which they reported as a land of terror-the former being habitually presented in the latitude of the Blaskets (Braschia), the latter nearly in that of the 
Isles de Sein, Brittany. This suggestion of possible prior discovery from the north-east of course does not at all refute the Breton expedition due westward, to which the Pizigani map bears explicit witness.

On the face of the matter it seems unlikely that either set of Celtic navigators would apply the same name to two radically different islands, especially as later cartography indicates that they would be slow to re. cognise them as belonging to one continuous coast. For not only were Labrador and Florida made islands on some early sixteenth-century maps, but sometimes the whole of the New World above South America was shown as an archipelago. It is true that Juan de La Cosa in 1500 . and Ruysch in 1508 presented a continental coast-line where maps now show North America, but they were in the minority. Granting, however, that the Irish or Breton discoverers would consider the second land an island like the first, it certainly does not at all follow that they would make the first island share its name with the second. We may more. reasonably assume that a different name was given, but was unknown to or forgotten by the Pizigani who made one word do double duty.

But "Brazir" did not adhere long to the Crescent Island. The very next map that we have, the remarkable Catalan Atlas of 1375, supplies. a more successful form in Mam (Man), very likely the correct and original one, which, significantly, is Celtic also. From times beyond history Man had been a notable island between Britain and Hibernia. Mananan in the oldest part of the ancient Foyage of Bran chants his song as a. sea-god encountered in his chariot above the waves. Mona, chief western seat of the British Druids-now Anglesea in North Wales-hardly varied the name. There was as good reason for applying it to oneAtlantic discovery as there had been for applying the equally ancient and equally mythical Brazil to another. It is true that the Catalan map. spells the word "Mam," but the final $m$ and $n$ were interchangeable, as. Pareto clearly shows in his fine map of 1455 , which unmistakably offers. us "Aragom," "hanc," and "Camaria," for Aragon, hanc, and Canaria. Moreover, we find the name plainly given as Man in the neat early fifteenth-century Venetian map attributed to Zuan da Napoli.

The Catalan Atlas is obviously quite independent of the Pizigani: work and information, at least as much so as the latter is of the Atlante. Mediceo. The first-named is very remarkable for a peculiar development of Brazil, the interior of which had merely been shown as rather cloudy by Dulcert : for on the Catalan map it becomes a circular sheet of water surrounded by a ring of land and dotted with islands. Of course. there is a meaning in this, perhaps the key to a notable geographicmystery. It was naturally repeated by divers later map-makers.

Man also is treated boldly and confidently by the Catalan, beingmuch larger in proportion to Brazil than in the Pizigani map, also much nearer to European waters, and for the first time shown in its fully. settled form of a broad crescent or disc-section with the western indentations reduced to regular scollops. This does not necessarily indicate anygreat antiquity in the tradition, for the mind of that age tended to artificial island-forms, as we see in many instances, and no great time seems: to have been needed for establishing one of these. But at least Man in. 
1375 , like Brazil in 1325, had become a recognised part of geography, and was regarded as a region barely less in extent. Also the cautious tendency to reduce western distances and draw islands towards Europe on the map was still at work.

The name Man had to compete almost at once with another. Though Soleri's map of about 1385 shows both the circular and crescent islands without names (not far from their places in the Catalan Atlas of 1375 ), the Pinelli map, 1384, almost identical in date, and an anonymous map of about the same period, concur in naming this island Jonzele. ${ }^{1}$ Possibly the name should read I. Onzele. Onza, in Italian, has for one of its meanings a section of a house or ship. In these maps the island is unusually small, a mere shred, curved but little, and not very unlike a longitudinal section of a ship's hull in miniature. Isola Onzele may conceivably refer to this, meaning the half-ship-shaped island. If so, it is the only one of Man's rather numerous names which seems to take account of its distinctive shape. Whether the conjecture be wholly satisfactory or not, there seems to be no other. A parallel instance is found in Tammar, so given in many works as it was formerly misread, but since discerned to be I. in Mar (Island in the Sea), and thus published in the fine copy of Beccaria's map of 1435, issued with Professor Magnaghi's monograph on the same by the Italian Geographical Congress of 1875 , under the auspices of the Italian Government. The running of the words together as one is rather common.

These two maps, unlike all other early ones, agree in bringing the islands together as a close pair near the latitude of Ushant in Northern Brittany, and not very far south of Ireland; the little crescent in each instance being north-east of its neighbour and turning its hollow the same way, both peculiarities the reverse of the established rule. In other respects these maps differ, notably in the form of Brazil; their divergences and their agreements, so soon after the entry of the Crescent Island into cartography, constitute one of the most insoluble minor problems of our inquiry. Apparently the cartographers were surest of two facts concerning Jonzele-that it had nearly the shape above mentioned, and that it lay in the latitude of Brittany. Their variants of one version of the geographic facts might be derived from two slightly differing narratives of one voyage, or two differing copies of one narrative.

That version was merely episodical, however. Neither the name nor any of the special features of delineation appeared again in maps, but tho Man (Mam) of the Catalan's ideal of 1375 reappeared early in the fifteenth century and held its ground for a hundred years. This is true of the shape and general style of the island, though the area and position vary more or less from type in exceptional cases; true also of the name, except that in some instances it is omitted, perhaps as unnecessary, or rarely changed a little. There is a general and rather close uniformity concerning it in the map of Zuan da Napoli, early fifteenth century, the anonymous Weimar map sometimes credited to 1424 and sometimes to 1481, the fifteenth-century Catalan map republished in Fischer's Samm-

1 Fiscler, scimmlung; vii. 11. 3 and 4. 
lun!, and the Italian and Catalan maps of Giraldi, 1426 ; Beccaria, 1426 and 1435 ; Bianco, 1436 and 1448 ; Benincasa, 1467 and 1482 ; Roselli, 1468 ; and Conde Freducci, 1497. Indeed, very few maps of the Atlantic prepared in that century were without this Crescent Island located and named as above stated.

A doubtful use of the name in that part of the ocean occurs two centuries earlier. A nearly elliptical world-map of the thirteenth century, copied by Santorem, indicates the Straits of Gibraltar by a gap in outline, which defines the position, as off Europe or off Africa, of the different oceanic islands, they being curiously represented by names in series following the curvature of the coast, though not drawn in any way. The continental names help us to place them, still rather uncertainly. The island names are parallel to the coast, and usually two deep, e.g. Thule and Dacie-perhaps Norway and Denmark-well at the top. Next above the straits we find the only instance of names three deep, apparently the three groups of the Azores. Next above these we have Man and Icoas, the former outside, the latter inside. Next above them are Roignegia and Ircadia ; the next pair still is Bputlandia ard Islandia, looking like a rather bad guess at a blurred Brittany and Ireland. Ircadia may possibly be the Orkneys. Beyond that it is rather wild guessing. Man and its partner are nearly opposite Flandria and Belgica. The first name, of course, may simply mean the island between Great Britain and Ireland; it is most unnaturally placed for this-but then on any theory the names have been shuffled about recklessly. Its position no doubt suits rather better the Crescent Island, far south-west of Ireland. Its companion Icoas must be something obsolete or a sad case of misreading and deformation. The initial letter may stand for island as usual. Coas is rather less unlike the separated middle part corus or colus of Pizigani's alternative name for Brazil (probably Montorius, as first written or uttered) than the name of any European island or shore which can be suggested. Such an explanation would bring the two insular regions Man and Brazil together at this early date, as was usual afterward; but it leans on too slender support." We can only say, on the authority of this map, that the name appeared in the Atlantic in the thirteenth century.

The word "Man" in Gaelic is said to have once meant "hand." It is at any rate identical with the first syllable of the Latin manus, and very much like the Portuguese derivative Mao, which has the same meaning. Bianco's chief innovation in nomenclature in 1436 was to change the name of the great rectangular island Saluaga or Salvagio, far west of the Azores and opposite Gascony and northern Spain, to La Man (or Mao) de Satanaxio. This has been commonly, no doubt correctly, understood as "The Hand of Satan," explained by a monstrous Oriental legend.

1 Lelewel, in his Géographie du Moyen Age, Atlas, presents the same map, with a different reading of the names. The one next to Man is made Scona. The two next above them are Norwegia and Islandia; three next below Anglia, Wallia, and I bernia. Perhaps his fancy may have been at work, as in applying the island names in the Elrisi restorations of his text maps. Yet he may be right in thinking this Man the one best known.

voL. XXXI. 
That island constitutes the second in size, and the most northern but one in position, of the conspicuous group of four large islands which Beccaria labels "Insulle de Novo Rep'te"-Recently Reported Islands. Of course there is nothing in its form or size or location to connect it with the Crescent Island; but the word Man has sufficed to make them pass for the same, at least conjecturally, with divers well-known writers. Yet the fact that Bianco himself shows both of the islands on one map with their characteristic forms, positions, and sizes, and in widely different parts of the ocean, ought surely to suffice as refutation. Evidently he had no fancy that any one would ever think of confounding them in any way.

The sixteenth-century cartographers for some reason preferred in most instances the equally curious name Mayda, which had many variants, as Mayde, Mayd, Maidas, Las Maydas, Asmaidas, Asmaida, and Asmandas. Asmaida was perhaps the first to appear-in the PtolemyAusgabe map of 1513. Humboldt ${ }^{1}$ seems to derive Asmaida from an Arabic word.of diabolical meaning, and thinks a suggestion of the latter character came from the supposedly infernal fires of volcanic islands farther southward. But this same map of 1513 turns Madera to Amadera, Gomera to Agomera, and Brazil or Brasill to O'Brassil. If these initial letters be not substitutes for the familiar I or Y, they seem to prove a fancy for meaningless prefixes of no more significance in the case of Mayda than any other. The name may be Arabic, but surely there is no more likelihood of that because the syllable "As" gives it an Arabic form. ${ }^{2}$ Bentusle, applied by Andreas Bianco to this island in 1448, has also been thought Arabic, presumably on account of the Semitic Ben; but it could be accounted for quite plausibly as a variant of ventus, with much the same meaning as Forteventura, being rendered "the windy island" on this Latin-derived basis.

However derived, Mayda is remarkable for its success in permanently supplanting, with rare exceptions, the long-established Celtic name. It is true that the maps of Ruysch, 1508, Thorne, 1527, Bordone and Coppo, 1528, and Ribero, 1529, do not show the island, but nearly all which do so call it Mayda. It is also true that the 1513 map above mentioned departs from the crescent form and shifts it southward a degree or two, though leaving the identification in other respects clear enough ; but this was soon remedied. For example, in a Portuguese map of 1519 or 1520 , reproduced by Kretschmer, which makes it crescent again in form, and moves it back to the forty-eighth parallel of North latitude.

Another Portuguese map, reproduced by Fischer, which curiously parallels in some important respects the Bianco map of 1448, and must be of the same period, reverts to "Mam," and slightly varies the inclination of the crescent, though otherwise regular and old-fashioned in its representation.

A more remarkable exception occurs in the American "Man" of Nicolas Nicolay, 1560. He puts "I Man or Bolunda" at the Straits of

1 Exant. Crit., vol. ii. pp. 244 and 245.

2 Exam, Crit,, vol, ii. p. $231_{*}$ 
Belle Isle above Verde, which seems to be a part of disintegrated Newfoundland, Brazil being a little farther out, perhaps in the western border of the Great Banks. Zaltieri of 1566 nearly repeats this position, though his islands are a little farther from the straits, and he uses Mayda, not Man, as a name. Ramusio, 1566, enlarged Maida to exceed Brazil in size, setting it well out at sea, but Gastoldi, illustrating Ramusio's text, about 1550 planted an isola de moni on the very site of Nicolay's really crescent Man, and very funnily illustrated the little demons there in wait and at play, as may be well seen in Justin Winsor's From Cartier to Frontenac. He also shared the common fancy of a brokenup Newfoundland, though his Island of Demons is a very large fragment. The "man" and "moni" of the latter two maps may have some connection beyond coincidence. Bolunda seems more like some native name. But the crescent form of the fourteenth and fifteenth centuries, the name appropriate thereto in the former, and the evil associations symbolised in Pizigani's monsters and hazy references to Arabic tales have all crossed the ocean to American waters. Humboldt noted this, but perhaps laid too much stress on volcanic fires and too little on the storm voices of upper Newfoundland, its sea-beaten cliffs, and ice ground wildly on the rocks. It is at least possible that distorted rumours of far western dangers and elemental complainings had first been carried to Europe, and afterward, in their island embodiment, shifted back to their place of origin, as men came to know that the sea really had a continental limit in that direction and where that limit lay.

But at this time another influence was at work, which soon relegated Mayda, like Brazil, to the yet unfamiliar waters of the middle ocean; for men were travelling up and down the American shore and growing sceptical of islands and wonders which they did not readily find - a mental condition promptly reflected on the maps. Thus Descelliers, drawing for Henry II. of France a very museum of strange sea-islands, some of which may be set down to sheer fancy-play under royal stimulation, had established Maida in latitude $53^{\circ}$ and a more eastern longitude than St. Michael; and Prunes, 1553, calling it Illa d'Mayd, had offered a neat instance of the accepted representation of the Crescent Island as to form and size, though less bulky than in some maps, and planted it in more southern waters than Descelliers, opposite Brittany, in mid-ocean, latitude $48^{\circ}$. Mercator, 1569 and 1587,1 and Ortelius, $1570,{ }^{2}$ beside their later issues, also kept the island remote from either shore, but gave it sometimes the surprising Flemish name Vlaanderen, which did not last on the maps, but had practically dissppeared by 1600 .

"Mayda" kept on through the centuries, always avoiding the greatly frequented shore-waters of both continents, usually accompanied by the crescent outline in diminished area, and merely exhibited more infrequently as scepticism grew. As instances, one may cite the As Maydas of F. de Witte, 1660, in about the longitude of Madeira,

1 Nordenskjöld, Facsimile Atlas, plate xlvii.

2 Schott, G., Geography of the Atlantic Ocean, p. 6, map. 
latitude of Brittany and Avalon Peninsula, Newfoundland ; a French map of 1771 showing Maida in latitude of Gascony, longitude of Palma in the Western Canaries; a Chart of Currents by Findlay, 1853,1 and a Relief Map of the World, first issued by the Central School Supply House, Chicago, in 1892 (latest U.S. copyright, 1906), which shows Mayda, thus named, about in the latitude of the mouth of the Loire and the longitude of Iceland. Negra's Rock and Jacket I. are also shown; but not Brazil (Island or Rock), nor even the undoubtedly real Rockall.

Negra's Rock, it may be said in passing, was reported by a skipper of that name near the end of the eighteenth century, according to a publication in the U.S. Hydrographic Office, but later investigations have not confirmed him, and the name represents nothing real — not even any really historic error.

Perhaps the ancient and evil reputation of the Crescent Islandwhich began its career in the company of dragons and other uncanny monsters, and two centuries later was still the playground of devils on the shore of the Straits of Belle Isle-may more or less account for Devil Rock, which appears in its stead on some moderately recent maps and in divers sea-captains' reports apparently given in good faith. The Hydrographic Office has kindly supplied a fow of these. Thus it appears that in 1737 Captain Brignon of the Constance placed it in latitude $46^{\circ} 55^{\prime} \mathrm{N}$. about 110 leagues WSW. of Ushant. It was again observed, in 1764, by Captain Thomas of Havre de Grace; as a rock three feet above water and forty feet in diameter, of a grey colour covered with moss, latitude $46^{\circ} 24^{\prime} \mathrm{N}$. and longitude $13^{\circ} 10^{\prime} \mathrm{W}$. In 1818 Captain Peter of the Bcothroct: reported it as of the same size in $46^{\circ} 35^{\prime} \mathrm{N}$. and $13^{\circ} \tau^{\prime} \mathrm{Tr}$. The sea broke over it. It was also reported by Captain Henderson of the Fortescue, in 1809, as twelve feet in diameter and two above water, by Captain Livingston of The Friends as a shoal in 1820, by Captain Swamson of the Fortitude in 1829, by.Lieutenant Sprigg of H.M.S. Brisli in 1842. But repeated soundings of governmental vessels have shown very deep water at divers points in the region where it is supposed to be, and the official conjecture is that the observers in question were misled by appearances on the surface of the sea.

Whether or not the possibility of a peak jutting up to the surface, like the Matterhorn from a very small base, is wholly eliminated must be left to the judgment of navigators. But, so far as the matter has been investigated, Devil's Rock seems to be a creation of seamen's fancy, prepared for in advance by the charts and maps showing Maida, and by dim lingering impressions of the perils attending the Crescent Isle, however named.

But it is not easy to believe the island itself-so constant in form and latitude, so variously named at different periods in different languages, so conspicuously and emphatically associated with at least

1 Westropp, Brczil, etc. (citel), p. 246. Humboldt, Exain. Crit., vol. vii. p. 163, citing Puriy. 
one definite expedition - to be wholly a product of fancy. If it be real it cannot be European, even in the sense of the remotest outpost, and there is nothing beyond this until you reach America. By turning more to the southward (as some of the maps of the fourteenth and fifteenth centuries make the slant from Brazil) we might admit the Bermudas to consideration, but they have always been counted American, though well offshore.

Their reputation in Shakespeare's time as the "still vexed Bermoothes," infested by Calibans and dangerous magic, seems to point that way. Also the crescent form is given to the main Bermuda island in the maps of Mercator, 1569, De Witte, 1660, and an undated French map, having 1669 for its latest discovery entry-perhaps it was made about 1700 . But neither the evil reputation nor the artificial form was the absolute monopoly of any island, as witness Inferno, which we now call Teneriffe, the Isle of the Dragon and the Isle of the Hand of Satan. Again, the crescent outline is occasionally given to Madeira, that most "fortunate island," sometimes to one of the Canaries, and always to Insula in Mar. The latitude seems low, yet need not be conclusive against it.

One difficulty is in guessing how much to allow southward from the 48th degree, on which we most often find the Man or Mayda of the older maps. If we cut this down to about $42^{\circ}$ we shall hit Cape Cod, a great sickle form protuberance of nearly insular land, which presents its concavity westward, and the outer corner of which has a bad name for hardships, dangers, and wrecks. These evils may once have been worse. Manifestly it fulfils many of the conditions imposed, and it is not possible to find a mainland stretch of coast north of Cape Hatteras that would do nearly so well.

Thus if Mayda be American, it seems most likely to be Cape Cod or Bermuda, with a slight preference for the former. Since some representatives of the Phonician peoples appear to have reached Corvo, presumably passing beyond; since the Irish of the early centuries of conversion undoubtedly reached Iceland and sailed farther still; since the Arabs apparently made the acquaintance of most of the eastern Atlantic islands, if they passed no farther, and since the Norsemen coasted the shore of mainland America and tried to settle there, it does not seem hard to believe that other maritime visitors from Turope, at various early times, may have reached some projecting points of the new world, which they regarded and named as islands, one of these being Man or Mayda.

That it successively bears the names of Celtic, Arabic, Italian and Flemish origin does not necessarily indicate a series of discoveries by different nations; but Pizigani's map is explicit as to a visit from Brittany. It is such a report as might be brought back by the adventurous Breton fishing fleet from its extreme far-western ranging among dangers. Persistent pushing might carry some of its members to Cape Cod or Bermuda, or storms might drive them there in disaster. This iseems more likely than entire invention of the tale which the Pizigani flags, ships, monsters and inscriptions have put on record. 